\title{
STUDIES ON THE DISINFECTION EFFICIENCY OF HOA SEN MEDICAL INSTRUMENT STERILIZING EQUIPMENT AT THE GENERAL, OBSTETRICS AND PAEDIATRICS HOSPITALS IN TRAVINH PROVINCE
}

\author{
Pham Hoang Long1, ${ }^{1,}$, Nguyen Hoai Chau ${ }^{1}$, Nguyen Chi Thanh ${ }^{1}$, Ngo Quoc Buu ${ }^{1}$ \\ ${ }^{1}$ Institute of Environmental Technology, VAST, Vietnam \\ Received 10 April 2019, accepted 15 August 2019
}

\begin{abstract}
This research aims to study on the disinfection efficiency of Hoa Sen medical instrument sterilizing equipment based on the application of ECA technology at General Hospital and Obstetrics and Paediatrics Hospitals in Tra Vinh. Disinfection using ECA technology is a method that does not require the introduction of special oxidizing agents except of water and salt. ECA solution - Anolyte solution has very strong oxidants, which oxidize components such as protein, lipid, etc. (usually of the bacterial cell membrane) that make the cell membrane decomposed, reducing $77-93 \%$ of the respiratory ability of bacterial cells, weakening them and eventually being destroyed. Hoa Sen medical instrument sterilizing equipment has a similar construction form as a regular double washing table with two wash basins, wherein one sink with a faucet which produces purified water, while other one has a faucet that gives anolyte solution for sterilization. Both faucets are based on a touch support. At the bottom of the sink an anolyte solution production system was installed. Valorization of the disinfection ability of the Hoa Sen medical instrument sterilizing equipment was based on the determination of the number of microorganisms on the surface of the instrument before and after being soaked with an antiseptic washing table. Microbiological criteria are the number of aerobic bacteria, E. Coli and Coliforms. Analytical samples were quantified by culture method on agar plates. Analysis of total aerobic bacteria, E. Coli and Coliforms bacteria according to Vietnam Standard TCVN 4884:2015, TCVN 6846:2007 and TCVN 6848:2007, respectively. The results showed that bacterial removal efficiency was elevated with a novel Hoa Sen sterilizing equipment anolyte. In laboratory scale, E. Coli and Coliforms bacteria with a density of $10^{5} \mathrm{CFU} / \mathrm{mL}$ were completely removed in $30 \mathrm{sec}$ contact with an anolyte solution of $300 \mathrm{mg} / \mathrm{L}$ active chlorine concentration. In hospital scale, the removal efficiency of total aerobic bacteria on the surface of medical instruments after surgery was $99 \%$ for one minute disinfection time. For E. Coli and Coliforms bacteria, the results of the analysis were not detected in both cases before and after sterilization.
\end{abstract}

Keywords: Anolyte, anti nosocomial infection, disinfection, electrochemical activation (ECA), Hoa Sen medical instrument sterilizing equipment.

Citation: Pham Hoang Long, Nguyen Hoai Chau, Nguyen Chi Thanh, Ngo Quoc Buu, 2019. Studies on the disinfection efficiency of Hoa Sen medical instrument sterilizing equipment at the general, obstetrics and paediatrics hospitals in Tra Vinh Province. Academia Journal of Biology, 41(3): 115-122. https://doi.org/10.15625/26159023/v41n3.13745.

*Corresponding author email: long.iet2006@gmail.com

(O2019 Vietnam Academy of Science and Technology (VAST) 


\section{INTRODUCTION}

To diagnose, care and treatment for patients in hospitals in Tra Vinh Province as well as across the country, it is indispensable to have medical instruments and sterilizing devices as one of the routes to prevent infection transmission. So sterilisation of medical instruments and their sterile state are very important to fight nosocomial infection. Pre-treatment of medical instruments and working space with high-effeciency disinfection agents is crucial step for restricting nosocomial infection in hospitals in Tra Vinh Province.

Currently most hospitals across the country are using imported solutions and chemicals to disinfect medical instruments such as Cidex OPA, Hexanios, Presept, etc (Nguyen \& Nguyen, 2009; Nguyen et al., 2015).

Hoa Sen medical instrument sterilizing equipment has a similar construction form as a regular double washing table with two wash basins, wherein one sink with a faucet which produces purified water, while other one has a faucet that gives anolyte solution for sterilization. Both faucets are based on a touch support. At the bottom of the sink an anolyte solution production system was installed.

Within 2-3 minutes in contact with anolyte solution, the medical instruments will be disinfected. Hoa Sen medical instrument sterilizing equipment helps technical workers and medical staff to immediately disinfect objects burdened with numerous pathogens.

\section{Disinfection mechanism with ECA solution}

Disinfection using ECA anolyte is a method that does not require the introduction of special oxidizing agents except of water and salt. Input materials are only water and chloride salt which is easy to find, cheap, environmental friendly, actually non-toxic to human health (Toropkov et al., 2001; Tomilov, 2002; Bakhir et al., 2003; Bakhir, 2014; Nguyen et al., 2015).

Figure 1 shows the flow diagram of the electrochemical chamber producing anolyte disinfectant solution:

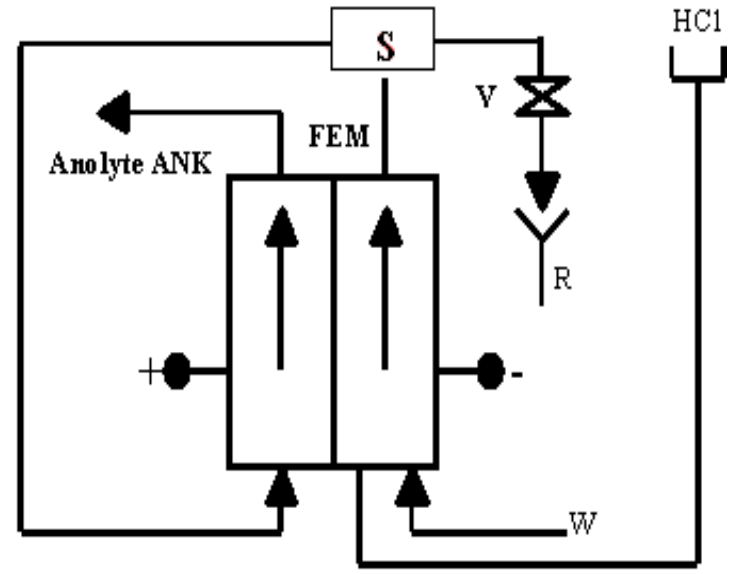

Figure 1. Flow diagram of electrochemical chamber producing anolyte disinfectant solution: W- Water with salt $(\mathrm{NaCl})$; S-

Catholyte separator; V- Adjustment valve;

FEM- Flow-through electrochemical module

In the diagram, dilute saline solution (1$5 \mathrm{~g} / \mathrm{L})$ is first run through the cathode chamber to raise the $\mathrm{pH}$ and saturate catholyte with hydrogen gas and then one part of the catholyte is sent to the anode chamber to receive neutral anolyte solution, while other part passes as catholyte.

Neutral anolyte (Anolyte ANK) has the following basic parameters:

Active constituents: $\mathrm{HClO} ; \mathrm{H}_{2} \mathrm{O}_{2} ; \mathrm{O}_{3}$; $\mathrm{ClO}^{*} ; \mathrm{HO}^{*} ;{ }^{*} \mathrm{O}_{2} \mathrm{H} ;{ }^{1} \mathrm{O}_{2} ; \mathrm{Cl}^{*}$;

Concentration of oxidants in term of active chlorine: $250-350 \mathrm{mg} / \mathrm{L}$;

$$
\mathrm{pH}=6.5-8.5 \text {; }
$$

ORP $=700-900 \mathrm{mV}$, (Pt electrode compared to $\mathrm{AgCl} / \mathrm{Ag}$ electrode).

Anolyte solution contains very strong oxidants, which oxidize components such as proteins, lipids, etc. (usually of the bacterial cell membrane) that make the cell membrane decomposed, reducing 77 to $93 \%$ of the respiratory ability of bacterial cells, weakening them and eventually being destroyed (Shimizu \& Hurusawa, 1992; Prilutsky \& Bakhir, 1997; Toropkov et al., 2001; Vorobjeva et al., 2003; Nguyen et al., 2015). 


\section{MATERIALS AND METHODS}

\section{Parameters of Hoa Sen medical instrument sterilizing equipment}

Figure 2 shows a photo of Hoa Sen medical instrument sterilizing equipment with a capacity of 10 liters of anolyte per hour. The equipment is made in the form of box, sus 304 stainless steel shell, and includes main parts: high-grade plastic sink, automatic control

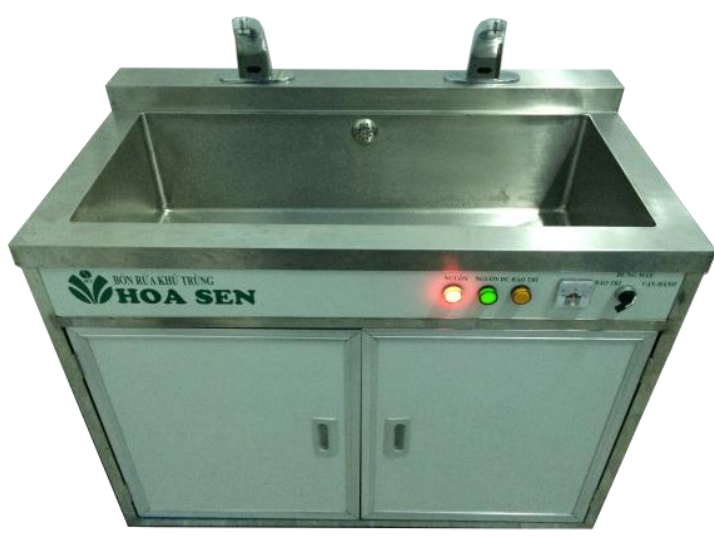

Figure 2. Equipment image (left) and installed at Tra Vinh General Hospital (right)

For production of anolyte solution Hoa Sen equipment uses only sodium chloride and water which are ubiquitously available and environmental friendly.

Anolyte solution can be used to wash hands directly, soak medical instruments to disinfect before being sterilized. In addition, valve, disinfection pump for a flow of 10 liters/hour, RO water filtration system with a capacity of 10 liters/hour, MB-11 electrochemical chamber with a capacity of 10 liters of anolyte per hour, automatic control cabinet, automat anti-shock, 10-liter product container and 2 automatic induction taps in which one for pure water supply and other one for anolyte solution.

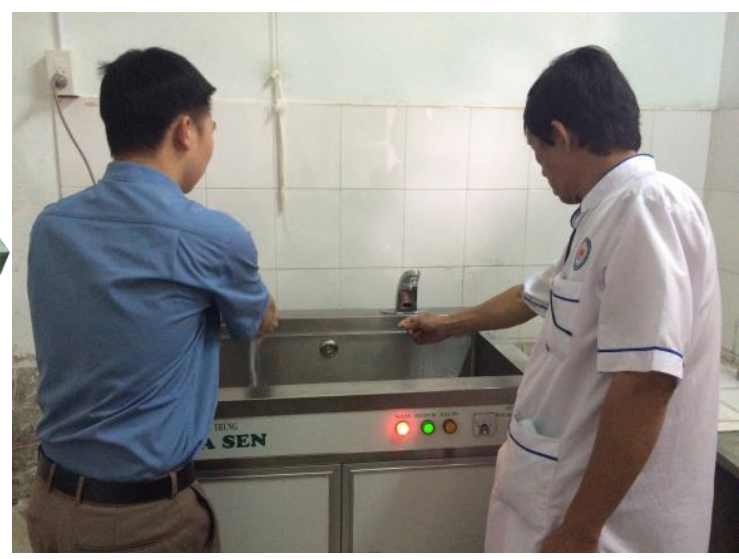

Table 1. Technical specifications of the Hoa Sen medical instrument sterilizing equipment

\begin{tabular}{|l|c|c|}
\hline \multicolumn{1}{|c|}{ Parameter } & Unit & Value \\
\hline Anolyte capacity & $\mathrm{L} / \mathrm{h}$ & 10 \\
\hline Active chlorine concentration & $\mathrm{mg} / \mathrm{L}$ & $300 \pm 50$ \\
\hline $\mathrm{pH}$ & - & $6,5-8,5$ \\
\hline Redox potential (ORP) & $\mathrm{mV}$ & $700-900$ \\
\hline Tank capacity & $\mathrm{L}$ & 72 \\
\hline Electricity consumption & $\mathrm{wh}$ & 150 \\
\hline Water consumption & $\mathrm{L} / \mathrm{h}$ & 15 \\
\hline Salt consumption & $\mathrm{g} / \mathrm{h}$ & 50 \\
\hline Size machine & $\mathrm{mm}$ & $900 \times 550 \times 830$ \\
\hline
\end{tabular}




\section{Methodology}

The equipment after manufacture is tested for the basic parameters of anolyte ECA solution and the sterilization feature of the device.

The basic parameters of anolyte ECA solution are measured by specialized fast measuring devices. Evaluation of the paremeters is performed by the Quality Assurance and Testing Center (Quatest).

Feature of the device is evaluated by experimenting for microorganisms exposed to anolyte ECA solution and then using agar plate method to determine CFU density (Colony-forming unit) before and after sterilization. The disinfection ability evaluation of the device was carried out by TVU Analysis - Testing Center (Tra Vinh University).

\section{Disinfection feature of Hoa Sen medical instrument sterilizing equipment}

Valorization of the disinfection ability of the Hoa Sen medical instrument sterilizing equipment was based on the determination of the number of microorganisms on the surface of the instrument before and after being soaked with an antiseptic washing table. Microbiological criteria are the number of aerobic bacteria, E. Coli and Coliforms (Vorobjeva et al., 2003; Nguyen \& Nguyen, 2009; Abdulsudi Issa-Zacharia et al., 2010; Nguyen et al., 2015).

\section{Determination of optimal time for sterilization}

The determination of optimal time for sterilization was carried out by adding $1 \mathrm{~mL}$ of suspension B to $9 \mathrm{~mL}$ of solution $\mathrm{A}$ at intervals of $0,5,10,30,60$ seconds, then remove residual chlorine with $\mathrm{Na}_{2} \mathrm{~S}_{2} \mathrm{O}_{3} 0.1 \mathrm{~N}$ and determine the density of $\mathrm{E}$. coli and Coliforms remained in the solution.
Solution A was anolyte solution prepared from Hoa Sen medical instrument sterilizing equipment with the basic parameters $\mathrm{pH}=$ $6,5-8,5$; Redox potential $(\mathrm{ORP})=700-900$ $\mathrm{mV}$; concentration of oxidants in terms of active chlorine $=300 \pm 50 \mathrm{mg} / \mathrm{L}$. Suspension B was a mixture of E. coli and Coliforms with density $10^{5} \mathrm{CFU} / \mathrm{mL}$.

\section{Determination disinfection efficiency of the Hoa Sen medical instrument sterilizing equipment}

The determination of the disinfection efficiency of the Hoa Sen medical instrument sterilizing equipment was based on the determination of the number of microorganisms on the surface of the instrument before and after being soaked with anolyte solution for one minute.

The microbiological surface sampling was carried out in accordance with the surface sampling guidelines in the "Aquatic Food Microbiology Test Handbook". SEAQIP, Agricultural Publishing House 2004.

\section{Microbiological analysis method}

The microbiological analysis of samples was carried out using the pour plate method. In this method, $1 \mathrm{~mL}$ of inoculum from a sample was placed in the center of sterile Petri dish using a sterile pipette. Molten cooled agar (approx. $15 \mathrm{~mL}$ ) was then poured into the Petri dish containing the inoculum and mixed well. After the solidification of the agar, the plate was inverted and incubated at $37^{\circ} \mathrm{C}$ for 24-48 hours.

PCA medium (plate count agar) was used for total aerobic bacteria; CCA (Chromocult Coliform Agar) for E. Coli and BGBB (Brilliant Green Bile Broth 2\%) for Coliforms.

\section{Determination the number of Colonies}

Count all the colonies that appear on the plates after incubation. Total bacterial density in $1 \mathrm{~mL}$ sample was calculated using Eq. 1.

$$
A=\frac{N}{n_{1} V f_{1}+\ldots+n_{i} V f_{i}}(C F U / g \text { or } C F U / m L)
$$


Where: $A$ is the number of cells (colony forming units) of bacteria in $1 \mathrm{~g}$ or $1 \mathrm{~mL}$ of sample, $N$ is the total number of colonies counted on selected petri disks, $n_{i}$ is the number of implants at $\mathrm{n}^{\text {th }}$ dilution, $V$ is the volume of sample solution $(\mathrm{mL})$ inserted into each disk, $f_{i}$ is the corresponding dilution.

In experiments, microbiological samples were taken by the cotton swab method on the determined surface. The bacterial density was calculated using Eq. 2.

$$
A^{\prime}=\frac{A \cdot V^{\prime}}{S} \quad\left(C F U / \mathrm{cm}^{2}\right)
$$

Where: $A^{\prime}$ is the number of cells (colony forming units) of bacteria in $1 \mathrm{~cm}^{2}$ of the sample; $V^{\prime}$ is the initial dilution volume; $S$ is sample surface area.

\section{RESULTS AND DISCUSSION}

\section{Determination of optimal time for sterilization}

Anolyte oxidation solution with an active oxidants content of about $300 \mathrm{mg} / \mathrm{L}$ is exposed to suspension $\mathrm{B}$ at intervals of 0,5 , $10,30,60$ seconds, the results are shown in Fig. 3, Fig. 4 and table 2.

The results in table 2 show that, with an anolyte solution of $300 \mathrm{mg} / \mathrm{L}$ active chlorine concentration, at 30 seconds of exposure: $E$. Coli and Coliforms bacteria with density of $10^{5} \mathrm{CFU} / \mathrm{mL}$ were completely removed.

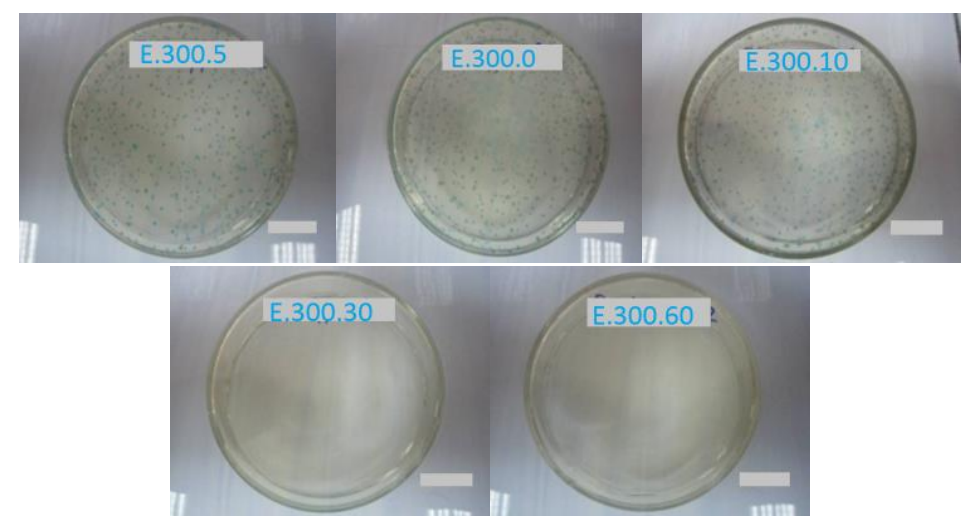

Figure 3. Density of E. coli bacteria on petri dishes after exposure with anolyte solution $[300 \mathrm{mg} / \mathrm{L}]$ at intervals of $0,5,10,30,60$ seconds

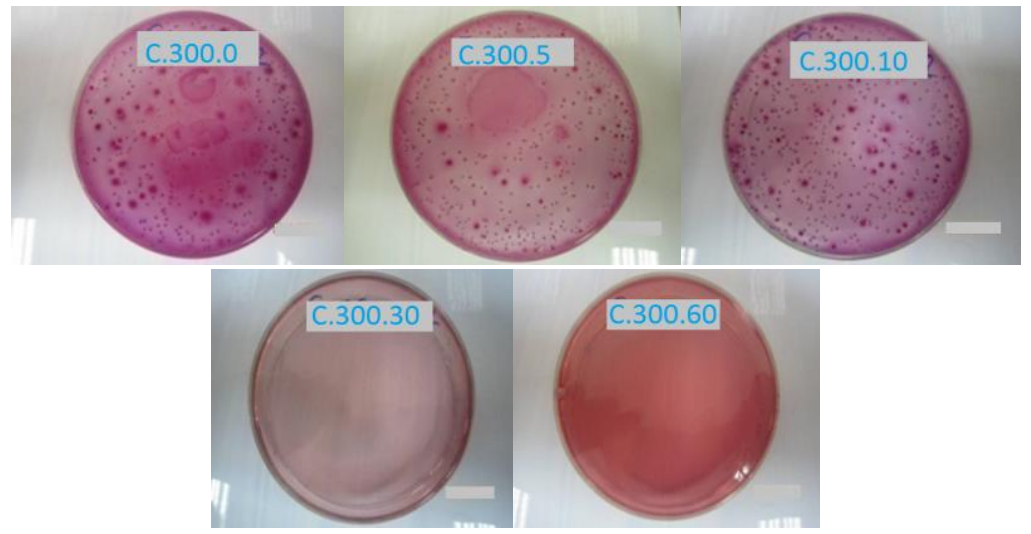

Figure 4. Density of Coliforms bacteria on petri dishes after exposure with anolyte solution $[300 \mathrm{mg} / \mathrm{L}]$ at intervals of $0,5,10,30,60$ seconds 
Table 2. Change of E. coli and Coliforms density by exposure time with anolyte solution [300 mg/L]

\begin{tabular}{|c|c|c|c|c|c|c|c|c|c|c|}
\hline Bacteria & $1^{\text {st }}$ Sample & $\begin{array}{c}2^{\text {nd }} \\
\text { Sample }\end{array}$ & $\begin{array}{c}3^{\text {rd }} \\
\text { Sample }\end{array}$ & $\begin{array}{c}4^{\text {th }} \\
\text { Sample }\end{array}$ & $5^{\text {th }}$ Sample & $\begin{array}{c}6^{\text {th }} \\
\text { Sample }\end{array}$ & $7^{\text {th }}$ Sample & $8^{\text {th }}$ Sample & $\begin{array}{c}9^{\text {th }} \\
\text { Sample }\end{array}$ & $10^{\text {th }}$ Sample \\
\hline \multicolumn{11}{|c|}{ Exposure time: 0 seconds } \\
\hline E. coli & $3.3 \times 10^{5}$ & $4.4 \times 10^{5}$ & $8.8 \times 10^{5}$ & $8.1 \times 10^{5}$ & $8.6 \times 10^{5}$ & $8.5 \times 10^{5}$ & $6.8 \times 10^{5}$ & $8.3 \times 10^{5}$ & $7.6 \times 10^{5}$ & $5.2 \times 10^{5}$ \\
\hline Coliforms & $2.0 \times 10^{5}$ & $4.7 \times 10^{5}$ & $8.2 \times 10^{5}$ & $6.9 \times 10^{5}$ & $9.2 \times 10^{5}$ & $8.3 \times 10^{5}$ & $7.9 \times 10^{5}$ & $8.1 \times 10^{5}$ & $8.5 \times 10^{5}$ & $6.8 \times 10^{5}$ \\
\hline \multicolumn{11}{|c|}{ Exposure time: 5 seconds } \\
\hline E. coli & $2.8 \times 10^{4}$ & $3.8 \times 10^{4}$ & $6.4 \times 10^{4}$ & $4.4 \times 10^{4}$ & $5.3 \times 10^{4}$ & $5.5 \times 10^{4}$ & $5.1 \times 10^{4}$ & $6.6 \times 10^{4}$ & $7.0 \times 10^{4}$ & $4.2 \times 10^{4}$ \\
\hline Coliforms & $1.1 \times 10^{4}$ & $4.2 \times 10^{4}$ & $6.2 \times 10^{4}$ & $5.6 \times 10^{4}$ & $7.8 \times 10^{4}$ & $7.5 \times 10^{4}$ & $6.2 \times 10^{4}$ & $6.4 \times 10^{4}$ & $7.8 \times 10^{4}$ & $5.3 \times 10^{4}$ \\
\hline \multicolumn{11}{|c|}{ Exposure time: 10 seconds } \\
\hline E. coli & $2.6 \times 10^{3}$ & $4.0 \times 10^{3}$ & $5.9 \times 10^{3}$ & $4.0 \times 10^{3}$ & $4.8 \times 10^{3}$ & $5.8 \times 10^{3}$ & $6.1 \times 10^{3}$ & $7.0 \times 10^{3}$ & $6.9 \times 10^{3}$ & $4.0 \times 10^{3}$ \\
\hline Coliforms & $1.6 \times 10^{3}$ & $4.1 \times 10^{3}$ & $6.0 \times 10^{3}$ & $4.8 \times 10^{3}$ & $7.7 \times 10^{3}$ & $7.3 \times 10^{3}$ & $6.9 \times 10^{3}$ & $7.1 \times 10^{3}$ & $7.7 \times 10^{3}$ & $5.5 \times 10^{3}$ \\
\hline \multicolumn{11}{|c|}{ Exposure time: 30 seconds } \\
\hline E. coli & 0 & 0 & 0 & 0 & 0 & 0 & 0 & 0 & 0 & 0 \\
\hline Coliforms & 0 & 0 & 0 & 0 & 0 & 0 & 0 & 0 & 0 & 0 \\
\hline
\end{tabular}


Determination disinfection efficiency of the Hoa Sen medical instrument sterilizing equipment

Table 3 shows the disinfection results of the Hoa Sen medical instrument sterilizing equipment for aerobic bacteria on the instrument surface after surgery. It can be seen that the bactericidal effect is more than $99 \%$ despite the contact time of only 1 minute.

For E. Coli and Coliforms bacteria, the results of the analysis were not detected in both cases before and after sterilization.

Table 3. Results of treatment of aerobic bacteria by Hoa Sen medical instrument sterilizing equipment*

\begin{tabular}{|l|c|c|c|}
\hline Aerobic bacteria & Before disinfection & After disinfection & Unit \\
\hline $1^{\text {st }}$ time & 26 & N.D & CFU $/ \mathrm{cm}^{2}$ \\
\hline $2^{\text {nd }}$ time & 31 & N.D & CFU $/ \mathrm{cm}^{2}$ \\
\hline $3^{\text {rd }}$ time & 23 & N.D & CFU $/ \mathrm{cm}^{2}$ \\
\hline $4^{\text {th }}$ time & 33 & N.D & CFU $/ \mathrm{cm}^{2}$ \\
\hline $5^{\text {th }}$ time & 35 & N.D & CFU $/ \mathrm{cm}^{2}$ \\
\hline $6^{\text {th }}$ time & 38 & N.D & CFU $/ \mathrm{cm}^{2}$ \\
\hline
\end{tabular}

Note: *: TVU Analysis - Testing Center (Tra Vinh University); N.D: Not detected.

\section{CONCLUSION}

The results of research on the application of ECA technology in the sterilization of medical instruments at the General Hospital and the Obstetrics and Paediatrics Hospital in Tra Vinh showed that Hoa Sen medical instrument sterilizing equipment demonstrates a high bactericidal ability and is safe for users. Equipment with salt and water inputs has overcome limitations encountered in existing medical disinfectants. Currently, two devices Hoa Sen medical instrument sterilizing equipments are being operated and used in the Department of Infection Control of two hospitals, contributing to anti nosocomial infection.

Acknowledgements: This research is funded by Vietnam Academy of Science and Technology (VAST) and the Department of Science and Technology of Tra Vinh province under grant number VAST.NĐP.02/17-18 "Research on the application of photocatalyst and ECA technology to enhance anti nosocomial infection in hospitals in Tra Vinh Province". We would like to express our sincerely thanks to Tra Vinh General Hospital, Tra Vinh Obstetrics and Paediatrics Hospital, TVU Analysis - Testing Center (Tra Vinh University) for kindly supporting us to implement this study.

\section{REFERENCES}

Issa-Zacharia A., Kamitani Y., Tiisekwa A., Morita K., Iwasaki K., 2010. In vitro inactivation of Escherichia coli, Staphylococcus aureus and Salmonella spp. using slightly acidic electrolyzed water. Journal of Bioscience and Bioengineering 110 (3): 308-313.

Bakhir V. M., 2014. Electrochemical activation. Technology. Application. Publishing house of Delfin Group: 512 pp.

Bakhir V. M., Leonov B. I., Panhicheva S. A., Prilutsky V I, Shomovskaya N Yu, 2003. Issues of chemical composition and operating properties of chlorine based inorganic liquid chemical germicides. VNIIIMT - Newsletter 4: 23-28.

Bakhir V. M., Vtorenko V. I., Prilutskii V. I., Schomovskaya N Yu., 2003. Economic background of application of STEL devices in medical-preventive institutions for synthesis of washing, disinfecting and sterilizing solutions. Medical Alphabet: 24-25 pp.

Nguyen H. C., Bakhir V. M., Ngo Q. B., 2015. Electrochemical Activation Solutions. Technology and Application. Publishing house of Natural Science and Technology: 316 pp. (In Vietnamese). 
Nguyen V. H., Nguyen H. C., 2009. Electrochemical activating solution and medical application. Journal of Chemistry 47 (5A): 209-214.

Panicheva S. A., 1998. New technologies for sterilization and disinfection of complicated items designed for medical use. M, VNIIIMT: 122 pp.

Prilutsky V. I., Bakhir V. M., 1997. Electrochemically activated water: abnormal properties, biological action mechanism. M, VNIIIMT: 228 pp, illustrated.

Shimizu E., Hurusawa T., 1992. Antiviral, antibacterial, and antifungal actions of electrolyzed oxidizing water through electrolysis. Dental Journal 37: 1055-1062.

Tomilov A. P., 2002. Electrochemical Activation (ECA) - new direction in Applied Electrochemistry. J. Life and Safety 3: 302-308.
Toropkov V. V., Altshul E. B., Toropkova E. V., 2001. Studies on parameters of neutral anolyte application for disinfection of water which is supplied to the population in a centralized and non-centalized ways. 3rd Int Symp on electrochemical activation: $218-225$.

Vorobjeva N. V., Vorobjeva L. I., Khodjaev E. Y., 2003. The bactericidal effects of electrolyzed oxidizing water on bacterial strains involved in hospital infections. Artificial Organs, 28: 590-592.

TCVN 4884-1:2015 (ISO 4833-1:2013): Horizontal method for the enumeration of microorganisms - Part 1: Colony count at 30 degrees $\mathrm{C}$ by the pour plate technique.

TCVN 6846:2007 (ISO 7251-1:2005): Horizontal method for the detection and enumeration of presumptive Escherichia coli - Most probable number technique.

TCVN 6848:2007 (ISO 4832:2007): Horizontal method for the enumeration of Coliforms - Colony - count technique. 